Jurnal Ekonomi Modernisasi

http:// ejournal.unikama.ac.id/index.php/JEKO

JEM 13 (2) 2017, 53-61

\title{
Penggunaan Organizational Culture Assesment Instrument pada Organisasi Non Formal
}

\author{
Ahmad Idris \\ Fakultas Ekonomi, Universitas Islam Kadiri
}

\begin{abstract}
The purpose of this study is to know the perceptions of the members of the community over the current organizational culture and expectations of the organizational culture members of the next 3 years. The research was conducted at Paguyuban Kios Selomangleng Kelurahan Sukorame, Kecamatan Mojoroto, Kota Kediri. This research used qualitative method with human instrument and participant observation data collection technique, and implemented organizational culture assessment instrument (OCAI) method. The results showed that the perception of members of Paguyuban Kios Selomangleng is currently in an adhocracy situation that is an organizational culture that demands innovation and initiative that can improve entrepreneurship and creativity. The hope of members of the community for the next 3 years is a market culture that is a condition where members want a competitive market culture to increase productivity and profit.
\end{abstract}

Keywords: adhocracy; organization culture; market

\section{Abstrak}

Tujuan penelitian untuk mengetahui persepsi anggota paguyuban atas budaya organisasi saat ini dan harapan anggota paguyuban budaya organisasi 3 tahun mendatang. Penelitian dilakukan pada Paguyuban Kios Selomangleng Kelurahan Sukorame, Kecamatan Mojoroto, Kota Kediri. Penelitian ini menggunakan metode kualitatif dengan human instrument dan teknik pengumpulan data participant observation, serta mengimplementasikan metode organizational culture assessment instrument (OCAI). Hasil penelitian menunjukkan bahwa persepsi anggota Paguyuban Kios Selomangleng saat ini berada pada situasi adhocracy yaitu budaya organisasi yang menuntut inovasi dan inisiatif yang dapat meningkatkan kewirausahaan dan kreativitas. Adapun harapan anggota paguyuban untuk 3 tahun mendatang adalah budaya market yaitu suatu kondisi anggota menginginkan budaya pasar yang kompetitif untuk meningkatkan produktivitas serta keuntungan..

Kata kunci: adhocracy; budaya organisasi; pasar

$$
\begin{aligned}
& \text { Permalink/DOI : http://dx.doi.org/10.21067/jem.v13i2.1767 } \\
& \text { Cara mengutip : Idris, A. (2017). Penggunaan Organizational Culture Assesment Instrument } \\
& \text { pada Organisasi Non Formal.Jurnal Ekonomi Modernisasi, 13(2), 53-61. } \\
& \text { doi:http://dx.doi.org/10.21067/jem.v13i2.1767 }
\end{aligned}
$$

Sejarah Artikel : Artikel diterima : April 2017; direvisi : Juni 2017; disetujui Juni 2017

\footnotetext{
Alamat korespondensi :

Fakultas Ekonomi, Universitas Islam Kadiri

Jl. Sersan Suharmaji No. 38 Kediri, Jawa Timur, Indonesia, 64128

E-mail: ahmad.idris22@gmail.com
} 


\section{Pendahuluan}

Jumlah penduduk Kota Kediri merupakan potensi dalam bidang sumber daya manusia yang dapat digunakan untuk membangun perekonomian Kota Kediri, namun demikian tidak semua penduduk Kota Kediri mempunyai usia produktif 15-64 tahun terserap dalam sektor tenaga kerja sehingga jumlah tenaga kerja tidak berbanding lurus dengan kesempatan kerja. Sesuai dengan yang dikemukakan oleh Ni Bulan, (2010) bahwa kesempatan kerja sangat terbatas dan tidak berbanding linear dengan jumlah lulusan. Oleh karena itu diperlukan upaya nyata untuk mengatasi kondisi tersebut. Salah satu upaya adalah meningkatkan jumlah wirausaha bagi yang mempunyai kenginan dengan sedikit pengetahuan dan pengalaman. Paguyuban Kios Selomangleng merupakan paguyuban wirausaha yang terletak di bagian barat sungai Brantas dan masuk kawasan lereng Gunung Klotok dan Gunung Maskumambang di wilayah kecamatan Mojoroto. Paguyuban Kios Selomangleng mempunyai peranan penting dalam memajukan perekonomian Kota Kediri terutama di kelurahan Sukorame dan kecamatan Mojoroto.

Saat ini Paguyuban Kios Selomangleng masih mampu bertahan karena keinginan anggota Paguyuban agar usaha yang dirintis tidak hanya menghasilkan keuntungan namun juga memberikan daya tarik bagi individu dengan karakteristik yang berbeda untuk bergabung dalam sebuah wadah Paguyuban. Daya tarik bagi anggota paguyuban adalah adanya manfaat materi dan non materi seperti terjalinnya komunikasi bisnis sesama para anggota se- hingga dapat menambah pendapatan atas usaha yang dimilikinya dan terjalinnya komunikasi sosial sehingga mereka dapat saling membantu meringankan permasalahan yang mereka hadapi selama bergabung dalam wadah paguyuban. Hal ini merupakan daya tarik individu yang mempunyai nilai non formal pada organisasi paguyuban ini.

Nilai non formal pada paguyuban ini tidak tertulis namun mempunyai peranan penting sebagai cara berpikir, menerima keadaaan dan merasakan sesuatu dalam anggota paguyuban tersebut. Budaya pada paguyuban ini memungkinkan organisasi tetap eksis. Hal ini sesuai dengan yang dijelaskan Soepardjo dan Nugrohoseno, (2014) bahwa budaya organisasi cenderung berhubungan dengan nilai-nilai atau norma -norma yang ada pada organisasi tersebut. Jika dalam organisasi tersebut berkembang suatu budaya kerja yang positif, maka akan menguntungkan aktivitas organisasinya. Sedangkan menurut Lestari dan Subagyo, (2013) menjelaskan budaya organisasi merupakan respon grup terhadap lingkungan yang diekspresikan oleh setiap individu di dalam grup tersebut. Tujuan penelitian ini adalah untuk mengetahui persepsi para anggota terhadap budaya organisasi yang ada pada saat ini dan harapan para anggota terhadap budaya organisasi pada tiga tahun yang akan datang.

\section{Tinjauan Pustaka}

Beberapa penelitian terdahulu tentang budaya organisasi sudah banyak dilakukan baik penelitian kuantitatif, kualitatif maupun gabungan. Penelitian yang dilakukan Monica, (2014) untuk keperluan memetakan profil budaya 


\section{Ahmad Idris / Analisis Budaya Organisasi....}

organisasi diperlukan elemen atau dimensi kunci yang akan membentuk atau memberikan arti terhadap perilaku anggota organisasi. Febriana dan Yuniawan, (2013) pada sebuah perusahaan perbankan menjelaskan profil budaya organisasi Bank Jateng dominan budaya hierarchy sedangkan harapan lima tahun yang akan datang adalah budaya market.

$$
\text { Indrawati dan Pratama, (2015) }
$$
menjelaskan untuk perusahaan yang bergerak di bidang informasi dominan budaya pasar karena mengedepankan inovasi dan mutu guna bersaing dengan perusahaan lain dalam memenangi persaingan. Tanuwibowo \& Sutanto, (2014) menjelaskan budaya organisasi dominan untuk bierarchy culture bagi karyawan karena adanya peraturan-peraturan yang mengikat para karyawan.

Menurut Cameron dan Quinn (1999) dijelaskan bahwa terdapat model pengukuran dan diagnosis budaya organisasi berdasarkan kerangka persaingan nilai. Model ini membagi budaya organisasi ke dalam empat tipe budaya yaitu: clan culture, adhocracy culture, market culture, dan bierarchy culture. Pengelompokan tipe budaya di atas berdasarkan pada empat variabel yang saling berkompetisi (competing values), yaitu stabilitas lawan fleksibilitas, pengawasan internal lawan posisi eksternal. Untuk menganalisis keempat tipe budaya digunakan enam kriteria yaitu karakter dominan, tipe kepemimpinan, tipe manajemen, perekat organisasi, penekanan strategi dan kriteria keberhasilan organisasi .

Penelitian tentang budaya organisasi menggunakan Organizational Culture Assessment Instrument pada umumnya menggunakan objek penelitian organisasi pemerintah atau swasta yang formal sedangkan obyek penelitian ini dilakukan pada organisasi non formal di masyarakat .

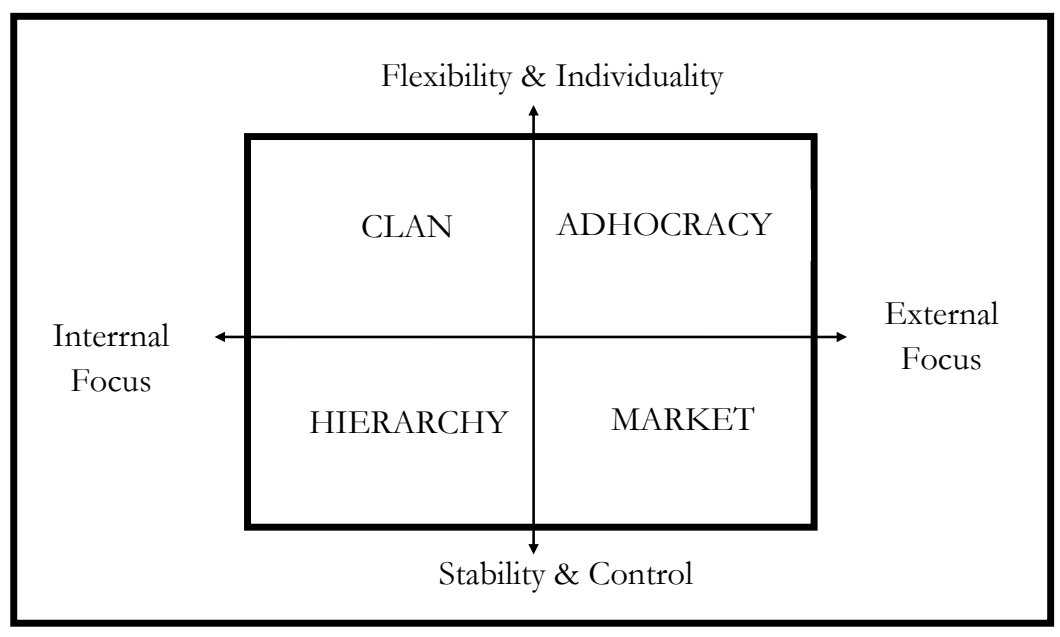

Gambar 1. Model Budaya Organisasi dalam Compecting Values Framework, Cameron dan Quinn 1999

\section{Metode}

Penelitian ini merupakan penelitian kualitatif karena menggali lebih dalam situasi sosial yang berkaitan dengan budaya organisasi menggunakan OCAI berdasarkan persepsi anggota Paguyuban Kios Selomangleng. Oleh karena itu, perlu dilakukan sebuah analisis mengenai budaya organisasi yang terjadi saat ini dan budaya organisasi yang diharapkan tiga tahun yang akan datang. Informan penelitian ini adalah 
anggota Paguyuban Kios Selomangleng yang memiliki jenis usaha yang berbeda- beda. Adapun kerangka pemikiran pada penelitian ini dijelaskan pada gambar 2 .

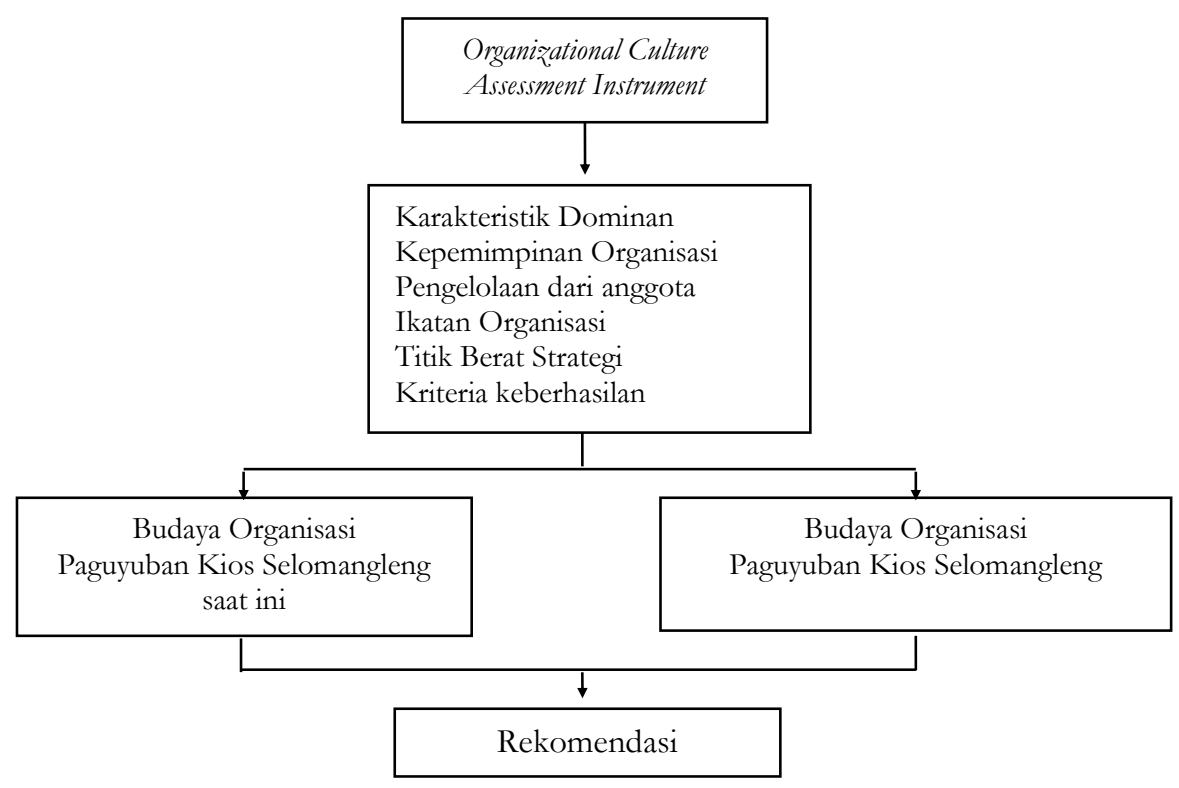

Gambar 2. Kerangka Pemikiran Konseptual

Penelitian ini dilakukan pada Paguyuban Kios Selomangleng yang disingkat PAKIS terletak di jalan Maskumambang, Kelurahan Sukorame, Kecamatan Mojoroto, Kota Kediri. Penelitian ini menggunakan instrumen kuesioner OCAI yang dibagi ke dalam enam dimensi, setiap dimensi ditunjukkan untuk mengetahui pandangan informan mengenai karakteristik dominan di paguyuban, kepemimpinan, pengelolaan anggota, perekat di organisasi, fokus strategi, dan kriteria keberhasilan yang dipandang penting oleh paguyuban. Informan dipilih dengan pertimbangan orang tersebut yang dianggap paling tahu tentang kondisi paguyuban. Sehingga dipilih sejumlah 3 (tiga) informan yang apabila kurang akan dicari informan berikutnya. Informan diminta untuk memberikan persentase pada setiap dimensi budaya berdasarkan kondisi saat ini dan kondisi yang diharapkan pada tiga tahun yang akan datang. Enam dimensi karakter (karakter dominan, tipe kepemimpinan, tipe manajemen, perekat organisasi, penekanan strategi, dan kriteria keberhasilan).

Setiap dimensi terdiri dari empat penyataan $\mathrm{A}, \mathrm{B}, \mathrm{C}$, dan $\mathrm{D}$ dimana $\mathrm{A}=$ budaya clan, $\mathrm{B}=$ budaya adhocracy, $\mathrm{C}=$ budaya market, dan $\mathrm{D}=$ budaya hierarchy dan memberikan persentase hingga totalnya menjadi 100\%. Langkah selanjutnya, skor akan diintepretasikan ke dalam sebuah chart dengan tipe radar pada microsoft excell sehingga dapat terlihat jelas kecenderungan budaya organisasi yang terjadi saat ini dan budaya yang diharapkan tiga tahun yang akan datang. Adapun indikator OCAI dapat ditinjukkan pada tabel 1 . 


\section{Ahmad Idris / Analisis Budaya Organisasi......}

Tabel 1. Indikator Organization Culture Assesment Instrumen

\begin{tabular}{|c|c|c|c|c|}
\hline Kriteria & Clan & Adhocracy & Market & Hierarchy \\
\hline $\begin{array}{l}\text { Karakteristik } \\
\text { Dominan }\end{array}$ & Kekeluargaan & $\begin{array}{l}\text { Dinamis dan } \\
\text { kewirausahaan }\end{array}$ & $\begin{array}{l}\text { Orientasi pada } \\
\text { tujuan }\end{array}$ & $\begin{array}{l}\text { Tempat } \\
\text { terstruktur dan } \\
\text { terkendali }\end{array}$ \\
\hline Kepemimpinan & $\begin{array}{l}\text { Mentor, } \\
\text { fasilitator }\end{array}$ & $\begin{array}{l}\text { Inovatif dan berani } \\
\text { mengambil risiko }\end{array}$ & $\begin{array}{l}\text { Agresif, berorientasi } \\
\text { pada hasil }\end{array}$ & $\begin{array}{l}\text { Koordinator, } \\
\text { mengatur dan } \\
\text { berorientasi } \\
\text { pada efisiensi }\end{array}$ \\
\hline $\begin{array}{l}\text { Pengelolaan } \\
\text { Anggota }\end{array}$ & $\begin{array}{l}\text { Teamwork, } \\
\text { konsensus dan } \\
\text { partisipasi }\end{array}$ & $\begin{array}{l}\text { Risk taking, memberi } \\
\text { kebebasan dan } \\
\text { keunikan }\end{array}$ & $\begin{array}{l}\text { Kompetitif, tuntutan } \\
\text { tinggi dalam prestasi }\end{array}$ & $\begin{array}{l}\text { Memberi rasa } \\
\text { aman, stabilitas } \\
\text { hubungan }\end{array}$ \\
\hline $\begin{array}{l}\text { Perekat di } \\
\text { Organisasi }\end{array}$ & $\begin{array}{l}\text { Kesetiaan dan } \\
\text { rasa saling } \\
\text { percaya }\end{array}$ & $\begin{array}{l}\text { Komitmen untuk } \\
\text { menciptakan inovasi } \\
\text { dan perkembangan }\end{array}$ & $\begin{array}{l}\text { Prestasi dan } \\
\text { pencapaian hasil, } \\
\text { agresif, dan } \\
\text { kemenangan }\end{array}$ & $\begin{array}{l}\text { Peraturan dan } \\
\text { kebijakan } \\
\text { formal }\end{array}$ \\
\hline Fokus Strategi & $\begin{array}{l}\text { Pengembangan } \\
\text { SDM, } \\
\text { kepercayaan } \\
\text { yang tinggi, } \\
\text { keterbukaan, } \\
\text { serya } \\
\text { partisipasi }\end{array}$ & $\begin{array}{l}\text { Penemuan baru, } \\
\text { mencoba hal-hal } \\
\text { baru }\end{array}$ & $\begin{array}{l}\text { Kompetisi dan } \\
\text { prestasi. Mencapai } \\
\text { target }\end{array}$ & $\begin{array}{l}\text { Efisiensi, } \\
\text { stabilitas, } \\
\text { kontrol, dan } \\
\text { kelancaran }\end{array}$ \\
\hline $\begin{array}{l}\text { Kriteria } \\
\text { Keberhasilan }\end{array}$ & $\begin{array}{l}\text { Pengembangan } \\
\text { SDM, } \\
\text { teamwork, } \\
\text { komitmen } \\
\text { anggota dan } \\
\text { kepedulian } \\
\text { terhadap } \\
\text { anggota }\end{array}$ & $\begin{array}{l}\text { Produk/layanan } \\
\text { terbaru. Pemimpin } \\
\text { dalam layanan/ } \\
\text { produk }\end{array}$ & $\begin{array}{l}\text { Memenangkan } \\
\text { kompetisi, menjadi } \\
\text { pemimpin di pasar } \\
\text { yang kompetitif }\end{array}$ & $\begin{array}{l}\text { Efisiensi, dapat } \\
\text { diandalkan, } \\
\text { jadwal rutin, } \\
\text { dan produk } \\
\text { dengan biaya } \\
\text { rendah }\end{array}$ \\
\hline
\end{tabular}

Sumber : Rangkuti 2012

Pemilihan informan pada penelitian ini dengan pertimbangan pengetahuan informan tas kondisi paguyuban. Oleh karena itu dipilih tiga informan yang apabila kurang akan dicari informan berikutnya. Informan diminta untuk memberikan persentase pada setiap dimensi budaya berdasarkan kondisi saat ini dan kondisi yang diharapkan pada tiga tahun yang akan datang. Enam dimensi karakter (karakter dominan, tipe kepemimpinan, tipe manajemen, perekat organisasi, penekanan strategi, dan kriteria keberhasilan) dimana setiap dimensi terdiri dari empat penyataan $\mathrm{A}, \mathrm{B}, \mathrm{C}$, dan $\mathrm{D}$ dimana $\mathrm{A}=$ budaya clan, $\mathrm{B}=$ budaya adhocracy, $\mathrm{C}=$ budaya market, dan
$\mathrm{D}=$ budaya hierarchy dan memberikan persentase hingga totalnya menjadi 100\%. Langkah selanjutnya, skor akan diintepretasikan ke dalam sebuah chart dengan tipe radar pada microsoft excell sehingga dapat terlihat jelas kecenderungan budaya organisasi yang terjadi saat ini dan budaya yang diharapkan tiga tahun yang akan datang.

\section{Hasil dan Pembahasan}

Paguyuban Kios Selomangleng pada tahun 2012 dengan 22 anggota dari warga masyarakat. Warga masyarakat berkumpul dan bersepakat untuk mendirikan sebuah perkumpulan usaha yang disebut Paguyuban 
Kios Selomangleng sebagai wadah kegiatan dan sarana komunikasi antara sesama warga yang menggunakan kios Selomangleng sebagai tempat usaha. Masa pemanfaat atau sewa Kios Selomangleng selama 20 tahun dari tahun 2010 sampai dengan tahun 2030 dan dapat diperpanjang kembali. Atas pemanfaatan tanah dan bangunan tersebut Paguyuban Kios Selomangleng membayar kontribusi/ retribusi per tahun kepada pemerintah Kota Kediri.Kegiatan-kegiatan yang pernah dilakukan seperti arisan, jalan santai, kerja bakti, hala bihalal, kunjungan wisata. Berikut jenis usaha anggota di Paguyuban Kios Selomangleng, (tabel 2).

Tabel 2. Jenis Usaha Paguyuban Kios Selomangleng

\begin{tabular}{cclccl}
\hline No & Kios & \multicolumn{1}{c}{ Jenis Usaha } & No. & Kios & \multicolumn{1}{c}{ Jenis Usaha } \\
\hline 1 & 1 & Laundry & 12 & 14 & Salon Kecantikan \\
\hline 2 & 2 & Tambal Ban & 13 & $15-16$ & Toko Bangunan \\
\hline 3 & 3 & Laundry & 14 & 17 & Warung Makan \\
\hline 4 & 4 & Air Minum Isi Ulang & 15 & 18 & Warung Makan \\
\hline 5 & 5 & Laundry & 16 & $19-20$ & Warung Makan \\
\hline 6 & 6 & Warung Makan & 17 & 21 & Sinar Fajar Aluminium \\
\hline 7 & 7 & Fotokopi & 18 & $22-23$ & Kost/Kontrakan \\
\hline 8 & $8-9$ & Gypsum & 19 & 24 & Kost/Kontrakan \\
\hline 9 & 10 & Accesoris Topi & 20 & 25 & Fotokopi \\
\hline 10 & 11 & Kost/Kontrakan & 21 & $26-27$ & Toko Kelontong \\
\hline 11 & $12-13$ & Barber Shop/Potong Rambut Pria & 22 & 28 & Warung Makan \\
\hline
\end{tabular}

Sumber : Data diolah Paguyuban Kios Selomangleng 2015

Berdasarkan hasil perhitungan skor tertinggi sebesar $30 \%$ persepsi anggota mengenai profil budaya organisasi paguyuban yang dirasakan saat ini adalah budaya adhocracy. Para anggota paguyuban cenderung merasa paguyuban kios selomangleng adalah tempat yang dinamis dan lahan kewirausahaan. Kepemimpinan paguyuban mengajarkan kepada anggotanya untuk inovatif dan berani mengambil resiko. Tipe Manajemennya memberikan kebebasan para anggota untuk menghasilkan produk atau tempat usaha. Perekat organisasi memperlihatkan komitmen untuk menciptakan inovasi dan perkembangan. Penekanan strategi memperlihatkan anggota untuk mencoba hal-hal yang baru. Kemudian yang terakhir kriteria keberhasilan dapat dilihat dari produk/layanan terbaru. Pada keenam dimensi yang ada di budaya adhocracy, dimensi yang paling kuat adalah dimensi perekat organisasi. Hal yang paling penting agar Paguyuban Kios Selomangleng tetap bertahan adalah keeratan hubungan antar anggota.

Tabel 3. Skor budaya organisasi menurut anggota saat ini

\begin{tabular}{lc}
\hline \multicolumn{1}{c}{ Budaya } & Skor \\
\hline Clan & 26 \\
\hline Adhocracy & 30 \\
\hline Market & 22 \\
\hline Hierarchy & 23 \\
\hline \multicolumn{1}{c}{ Total } & 100 \\
\hline
\end{tabular}

Sumber : Data diolah 2015 


\section{Ahmad Idris / Analisis Budaya Organisasi.....}

Tabel 4. Skor budaya organisasi menurut anggota 3 tahun mendatang

\begin{tabular}{lc}
\hline \multicolumn{1}{c}{ Budaya } & Skor \\
\hline Clan & 26 \\
\hline Adhocracy & 26 \\
\hline Market & 27 \\
\hline Hierarchy & 21 \\
\hline \multicolumn{1}{c}{ Total } & 100 \\
\hline
\end{tabular}

Sumber : Data diolah 2015

Profil budaya yang diharapkan 3 tahun yang akan datang adalah budaya market, yaitu suatu kondisi dimana anggota paguyuban mengingkan budaya pasar yang kompetitif, serta perilaku konsumen cenderung memilih dan tertarik pada nilainilai sehingga menempatkan Paguyuban Kios Selomangleng pada organisasi bisnis yang selalu berusaha meningkatkan persaingan. Tugas utama pengurus paguyuban adalah mengendalikan organisasi untuk mencapai produktivas, hasil, tujuan serta keuntungan.

Profil budaya yang cenderung diharapkan pada 3 tahun yang akan datang adalah budaya market, suatu kondisi dimana anggota paguyuban mengingkan budaya pasar yang kompetitif, serta perilaku konsumen cenderung memilih dan tertarik pada nilai-nilai sehingga menempatkan paguyuban kios selomangleng pada organisasi bisnis yang selalu berusaha meningkatkan persaingan. Tugas utama pengurus paguyuban adalah mengendalikan organisasi untuk mencapai produktivas, hasil, tujuan serta keuntungan. Berikut disajikan persepsi anggota paguyuban dalam bentuk gambar saat ini dan 3 tahun mendatang, (gambar 3)

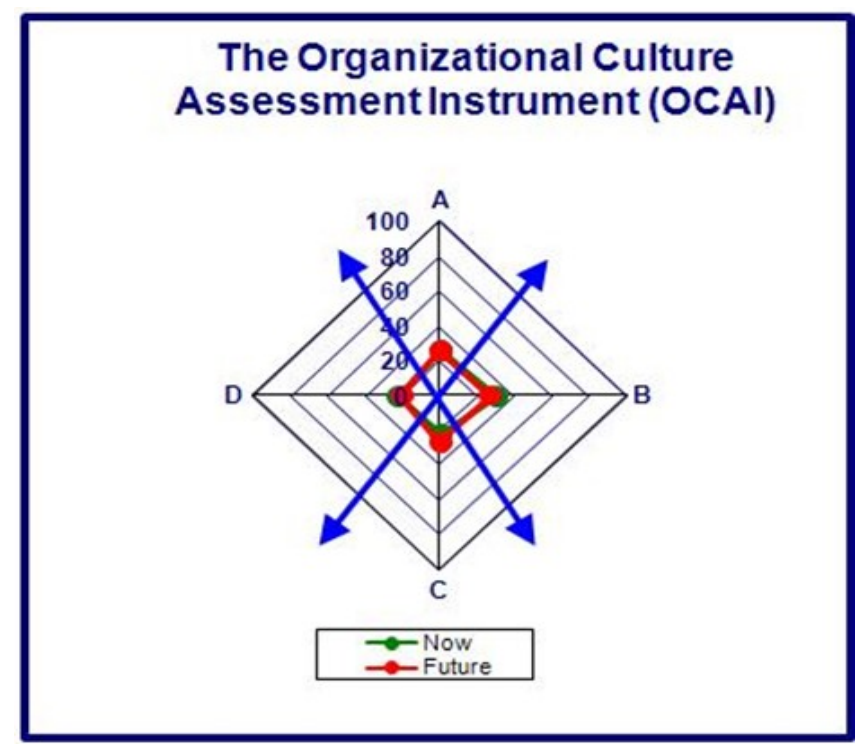

Gambar 3. Profil budaya organisasi saat ini dan 3 tahun mendatang

Pada gambar 3. dapat diketahui garis yang berwarna hijau menunjukkan profil budaya saat ini dan garis berwarna merah adalah profil budaya yang diharapkan anggota paguyuban pada 3 tahun mendatang. 
Berdasarkan hasil analisis yang telah dilakukan dengan menggunakan model OCAI, diketahui Paguyuban Kios Selomangleng tidak memiliki budaya yang kuat menurut keempat alternatif budaya yang ada pada Competing $V$ alues Framework $(\mathrm{CVF})$. Kecenderungan persepsi anggota paguyuban mengarah pada budaya adhocracy sementara persepsi anggota paguyuban untuk 3 tahun kedepan mengarah pada budaya market.

Budaya yang kuat dipastikan dimiliki anggota yang termotivasi dan berkomitmen tinggi. Budaya organisasi yang kuat juga merupakan alat kendali perilaku manusia yang efektif sekaligus efisien. Budaya organisasi yang lemah tidak mampu membuat anggota paguyuban mengidentifikasikan diri mereka dengan tujuan paguyuban dan bersama-sama untuk mencapai tujuan organisasi. Langkah yang bisa ditempuh adalah membuat visi dan misi dan tujuan yang akan dicapai oleh Paguyuban Kios Selomangleng. Langkah selanjutnya adalah menetapkan budaya organisasi sebagai salah satu strategi dalam upaya mencapai visi, misi dan tujuan tersebut. Langkah berikutnya setelah menetapkan budaya apa yang akan diterapkan oleh paguyuban, akan dirumuskan kebijakan-kebijakan yang terkait dengan perubahan budaya organisasi. Kemudian sosialisasi dan yang terakhir adalah evaluasi. Layaknya sebuah strategi, setiap akhir pelaksanaannya selalu diadakan evaluasi guna melihat sejauh mana efektivitas strategi yang dibuat dalam mencapai visi, misi dan tujuan paguyuban.

\section{Simpulan}

Persepsi anggota Paguyuban Kios Selomangleng pada saat ini cenderung berada pada situasi budaya adhocracy merupakan budaya organisasi yang menuntut inovasi dan inisatif serta menciptakan produk baru dan jasa untuk mengantisipasi dan mempersiapkan kebutuhan masa depan. Tugas utama pengurus paguyuban adalah mendukung dan mendorong terciptanya semangat kewirausahaan dan kreativitas. Persepsi anggota paguyuban kios selomangleng untuk 3 tahun mendatang adalah budaya market, suatu kondisi dimana anggota paguyuban menginginkan budaya pasar yang kompetitif, serta perilaku konsumen cenderung memilih dan tertarik pada nilainilai sehingga menempatkan Paguyuban Kios Selomangleng pada organisasi bisnis yang selalu berusaha meningkatkan persaingan. Tugas utama pengurus paguyuban adalah mengendalikan paguyuban untuk mencapai produktivas, hasil, tujuan serta keuntungan.

Rekomendasi yang dapat dirumuskan bagi paguyuban kios selomangleng untuk mengembangkan budaya organisasi yang perlu dilakukan adalah menetapkan visi, misi dan tujuan paguyuban sehingga budaya organisasi yang diharapkan jelas dan keuntungan/kemakmuran dirasakan oleh seluruh anggota Paguyuban Kios Selomangleng semakin meningkat.

\section{Daftar Pustaka}

Cameron, K. S., \& Quinn, R. E. (1999). Diagnosing and changing organizational culture. Reading: Addison-Wesley

Febriana, A. T., \& Yuniawan, A. (2013). Analisis pemetaan budaya organisasi menggunakan organizational culture assessment instrument pada PT. Bank Pembangunan Daerah Jawa Tengah. Jurnal Studi Manajemen \& Organisasi, 10(1), 82-97.

Indrawati, N. S., \& Pratama, D. A. (2015). Analisis budaya organisasi model OCAI (organizational culture assessment instrument) dan motivasi kerja hirarki kebutuhan abraham maslow karyawan pada PT Telekomunikasi Indonesia, Tbk Bogor. Jurnal Ilmiah Manajemen Fakultas Ekonomi, 1(2), 79-85. 


\section{Ahmad Idris / Analisis Budaya Organisasi.....}

Lestari, H., Wijaya, A. R., \& Subagyo. (2013). Pengukuran budaya organisasi pada industri minuman di Jawa Tengah untuk meningkatkan daya saing di era global. Prosiding SNST ke-4, 20-25. Semarang : Universitas Wahid Hasyim.

Ni Bulan, T. Rondang. (2010). Budaya organisasi terhadap peningkatan kinerja pelaku ukm di lingkungan industri pembuatan tahu. Jurnal Keuangan \& Bisnis, 2(3), 207-216.

Rangkuti, Freddy. (2012). SWOT Balanced Scorecard Teknik Menyusun Strategi Korporat yang Efektif plus Cara Mengelola Kinerja dan Risiko. Cetakan ketiga. Jakarta : PT. Gramedia Pustaka Utama.
Soepardjo, T. A., \& Nugrohoseno, D. (2014). Pengaruh budaya organisasi dan komitmen organisasi terhadap kinerja karyawan. Jurnal Ilmu Manajemen, 2(4), 1783-1793.

Tanadi, Monica. (2014). Pemetaan budaya organisasi di PT. Wisata Dewa Tour dan Travel tahun 2013. E-Journal Graduate Part A-Economics, 1(1), 45 $-67$.

Tanuwibowo, J. C., \& Sutanto, E. M. (2014). Hubungan budaya organisasi dan komitmen organisasional pada kinerja karyawan. Trikonomika, 13 (2), 136-144. 